\title{
Market prospects for Acadian forest products in the context of future energy availability
}

\author{
by Peter Salonius ${ }^{1}$
}

\begin{abstract}
As the peak of non-renewable energy production passes during the next forest rotation it is expected that markets, which have recently been driven by pulp and paper and dimension lumber exports, will shrink due to a general decrease in the affluence of the customer base and attrition in its numbers. An expected increase in demand for forest biomass fuels should begin to influence present silvicultural investment decisions now. Emphasis on the production of softwood fibre for commodity markets should yield to emphasis on the restoration of diverse Acadian temperate forest species assemblages. Means of encouraging a shift in harvesting practices in advance of changes in market demand are discussed.
\end{abstract}

Key words: energy scarcity, market alteration, silvicultural investments

\section{RÉSUMÉ}

À mesure que l'on s'approche de la production maximale d'énergie non renouvelable devant s'effectuer au cours de la prochaine révolution forestière, il est prévu que les marchés qui ont été dernièrement menés par les exportations de pâte et de papier et de bois de construction, vont se contracter par suite d'une diminution générale de l'affluence des clients et de la répartition des classes d'âges. Une augmentation prévue de la demande de combustibles tirés de la biomasse forestière devrait commencer à influencer dès maintenant les décisions actuelles d'investissement sylvicole. L'accent sur la production de fibre de résineux pour les marchés de produits courants devrait céder sa place pour accroitre la restauration de divers assemblages d'espèces forestières de la forêt acadienne tempérée. Les moyens d'encourager un changement dans les pratiques de récoltes en prévision des modifications de la demande des marchés sont abordés dans cet article.

Mots clés : rareté de l'énergie, modification des marchés, investissements sylvicoles

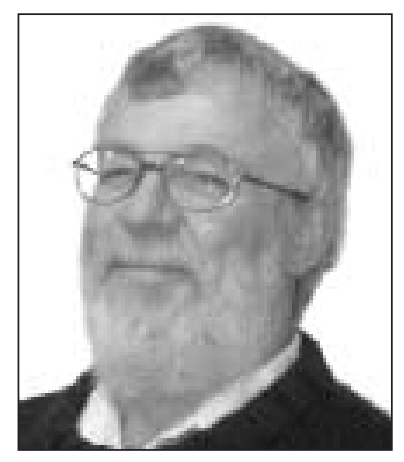

Peter Salonius

\section{Introduction}

A six-fold global population expansion and the evolution of global trade, during the last two centuries, has been made possible by access to unprecedented amounts of cheap and abundant non-renewable energy that have been extracted from geological stores (Campbell 2002, Watt 2003). In spite of mounting evidence that fuel scarcity and resulting price escalation will have a profound

effect on the energy intensive North American economy, forest operations, planning and the policies associated with this planning have not apparently varied from the pattern of increasing silvicultural intensification that has been established in recent decades. The inevitable energy scarcity (Youngquist 1999, Dukes 2003) is expected to diminish demand for conventional forest commodities and preclude their transport to distant markets. Silvicultural investment decisions, made now, must consider probable market conditions at the end of the rotation of trees that are currently regenerating.

Further intensification of forest practices has recently been recommended to double the softwood harvest in New
Brunswick (Jaakko Pöyry Consultants 2002), much of which has been historically marketed to the construction industry in the expanding economy of the United States. Oliver (1999) suggested that all policy directions require government intervention, and that decisions will be necessary that lead to either intensive and energy-demanding plantation forestry on a limited land base coupled with reserves, or to integrated management where high intensive silviculture costs are replaced by harvest methods based on ecological understanding. Benson (1990) stated that most of the large, less productive forests in Canada should be managed extensively with inexpensive natural regeneration achieved by modified harvesting, instead of intensively with the energy-demanding plantation management that is employed in areas with much longer growing seasons.

While the creation of small harvest openings by single-tree selection is difficult for modern harvesting machinery and produces low diversity, shade-tolerant regeneration (Johnson 1984, Guldin 1996, Crow et al. 2002), harvesting by mechanical systems is a more practical and inexpensive option for clearcut harvesting systems in strips or patches that are designed to favour a wider diversity of natural regeneration (Franklin and Forman 1987).

A continuation of the intensive silviculture systems that have been applied in the Acadian forest region, incurring considerable long-term investment, can only be considered if future market conditions are forecast to be an extension of

522 Route 8 HWY, Durham Bridge, New Brunswick E6C 1K5. E-mail: petersalonius@hotmail.com 


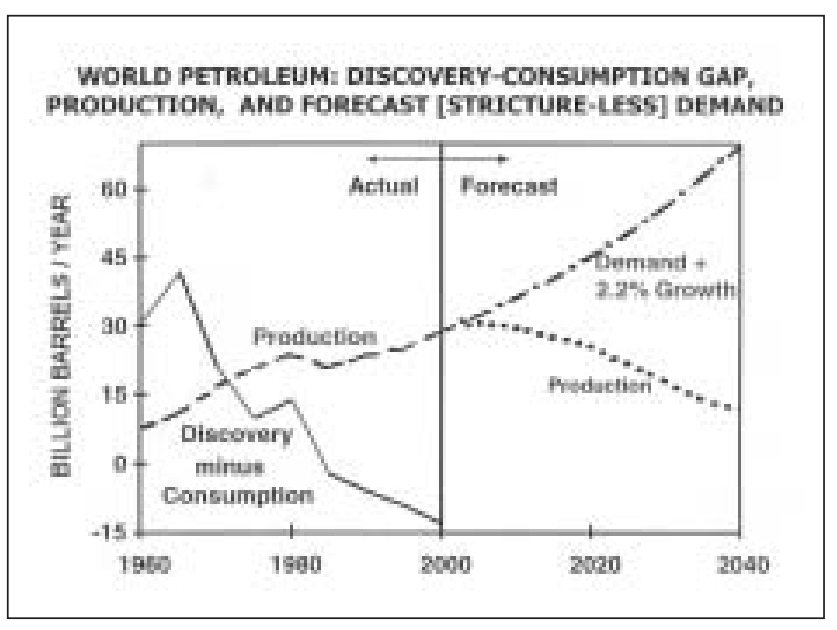

Fig. 1. World petroleum: discovery minus consumption, production and demand

the present economy that is dominated by exponential population growth, economic expansion, and increasing global trade, all of which depend on cheap and abundant energy. There has been little discussion of the implications of future energy scarcity for society in general, and virtually no discussion of these implications for the forest industry. This incomplete world view is not unexpected since few people are paid or promoted to perform forecasts for large systems (Watt 2003).

\section{Forecast Future World Energy Supplies}

A major shift from solar to fossil hydrocarbon energy sources since 1750 has made civilization vulnerable, both to decreases in the total supply of these non-renewable resources and to the inexorable decline of energy returned on energy invested (EROI) as large, easily accessed deposits have been depleted (Hall et al. 2003). Petroleum geologists predict that the peak and gradual decline of world oil and gas production will unfold within the next few decades (Campbell and Laherrere 1998, Duncan and Youngquist 1998, Deffeyes 2001). Energy demand driven by rising population, a rapidly developing affluent middle class in Asia (Calder 1996), and continuing expansion of global trade, would increase consumption exponentially at about $2 \%$ annually in the absence of scarcity (Campbell 2002). Annual petroleum production from 1960, projected decline in future production (Duncan and Youngquist 1998), future demand if growth were possible, and the developing negative relationship between discovery and consumption (Campbell and Leherrere 1998) are summarized in Fig. 1.

Peak petroleum production is expected to force a transition from the abundant, cheap and convenient energy that has facilitated expanding economies and global markets, toward less abundant, more expensive and much less flexible energy that will force a contraction of the world economy and a return to more local trading patterns. This transition will have profound implications for the export-dependent Canadian forest industry and its reliance on distance transport, because the anticipated deepening mismatch between petroleum supply and demand will develop during the same time frame as the maturation of the next rotation of trees.

\section{Population, Economic Growth, and Trading Pattern Responses to Energy Scarcity}

A discussion of the relationship of world energy supplies to population growth and affluence projections, upon which future market expectations are built, is necessary because the implications of this relationship have not been incorporated into long-term planning for societies in most countries (Campbell 2002) or into investment strategies in forestry. The Brundtland Commission (World Commission on Economy and Environment 1987) predicted a five- to tenfold increase in the size of the global economy before the world population would stabilize some decades hence; however, long-term economic and social planning based on such predictions may be seriously flawed as a result of an inadequate appreciation of the dependence of expanding economic activity upon finite geological energy stores (Cleveland et al. 1984, Tainter 1990). Oil and gas provide the major energy base for modern globalized economies and there are no apparent substitute sources to replace the vast amounts of energy currently used as peak production is reached and annual declines in supply commence (Ivanhoe 1996, Youngquist 1997).

The relationship between cheap, abundant, exogenous, non-renewable energy and population numbers that temporarily exceed the carrying capacity of land (Smil 1997) is described by the statement of Bartlett (1978) that "modern agriculture is the use of land to convert petroleum into food." Abernethy $(1997,2002)$ showed that sharp declines in birth rates rapidly follow catastrophic economic collapse resulting from resource scarcity. Both Campbell (2002) and Watt (2003) have linked the rapid rise in human population numbers during the last 200 years to the temporary availability of inexpensive and abundant non-renewable geological energy stores. Stanton (2003) predicted limits on economic expansion, in the absence of some new energy source like nuclear fusion, as human numbers begin to return to levels that can be supported by solar energy. A diagrammatic conception of past population growth, global trade and non-renewable energy use, with posited future declines toward a much smaller steady-state economy, is presented in Fig. 2.

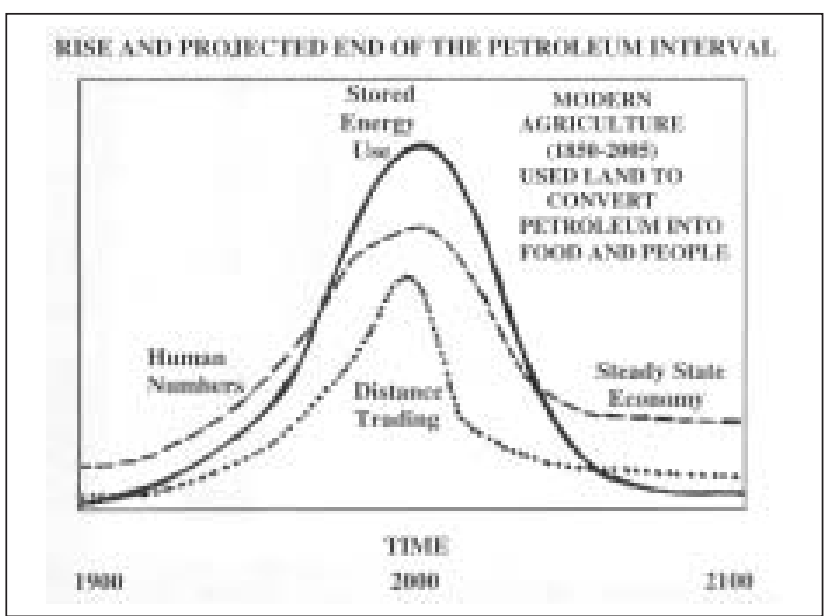

Fig. 2. Rise and projected decline of geological energy stores, population and global trading 


\section{Prospects for a Smooth Transition to Renewable Energy}

The enormity of current energy use is indicated by the fact that annual consumption of fossil energy in the United States exceeds that captured by all of the plant mass in the country (Youngquist 1997, Pimentel et al.1999). Pimentel et al. (1994) have calculated the tremendous amounts of land that would be required to partially replace current exhaustible energy use with renewable energy. The transient nature of the energydependent growth economy has been compared to the sustainability of a steady-state economy, supposing a choice between these avenues were possible (Daly 1991). The economics community, which has become accustomed to openended population and economic expansion, is almost completely unprepared to deal with a steady-state economy (Hardin 1993). As populations and their economies overshoot the physical limits of the Earth, its resource base, and the solar-based carrying capacity, the only apparent options are an involuntary collapse caused by escalating shortages, or a controlled reduction of the total human enterprise by deliberate social choice (Meadows et al. 1992). The pace of the shift from an economy dependent on fossil fuel to a renewableenergy-based economy will be orchestrated by how society plans for the transition (Duchesne and Wetzel 2003). Government action is necessary to address the inability of the market system to price energy according to its long-term abundance (Campbell 2002) by the employment of such innovations as tax shifting to progressively increase the price of non-renewable energy so as to make research, development and market intrusion of renewables more attractive and to render the transition less painful (Salonius 2003). The transition toward the use of increasing amounts of renewable energy is well established in a few countries, such as Sweden and Finland, as a result of graduated taxation on various energy sources that encourage increasing utilization of solarbased energy (Hakkila 2004).

\section{Management for Biomass and Forest Restoration}

Forest products will increasingly be valued for space heating and electricity production as well as a source of liquid fuels for transport, such as biomass-based methanol (Ohlström et al. 2000, Doty 2005). Prices offered for combustible waste (sawdust, wood, and bark) from forest product manufacturing are already approaching those offered for raw pulpwood in New Brunswick. Given the prospect of increasing demands on the forest for biomass, greatly decreased investments can be expected for site preparation, most planting, chemical competitor control, and tree improvement, which have recently dominated the practice of intensive silviculture. Gladstone and Ledig (1990) suggested that increased highyield wood production on forest farms and recovery of all above-ground biomass can spare native forest; however, complete biomass removal has since been shown to lower longterm site productivity because of the export of scarce nutrients in post-harvest slash and thinnings (Hakkila 2004). The prospect of decreasing pressure to produce specific forest products such as coniferous pulpwood and saw timber for both the domestic market, and especially for a future contracting economy in the United States (Heinberg 2005), may influence forest managers to concentrate their efforts on maintaining biodiversity and forest health by the use of harvesting systems that emulate natural disturbance dynamics, because industry is not particular about the type of wood it uses as fuel or as a feedstock for organic chemical production.

Human-orchestrated approximation of Acadian forest gap replacement dynamics would produce forest microclimates, similar to presettlement conditions, from the standpoint of the organisms and biological processes (many of which are unknown) that constitute fully functioning forest ecosystems. The adoption of altered forest harvesting methods that preserve and restore biodiversity, by approximating natural disturbance patterns, should alleviate the constantly increasing political pressure for the creation of more small isolated ecological reserves that are essentially islands in a landscape of unnatural disturbance and that condemn many species to ultimate extinction (Diamond 1975, Matlack 1994, Trombulak 1996). The assertion by Freedman et al. (1994), that biological diversity can only be preserved in ecological reserves, is seen by this author as a "museum" strategy that will be unsuccessful in the long run.

Restoration strategies, employing alternatives to large harvest blocks that require energy intensive reforestation, should not attempt to predetermine which species will predominate (Trombulak 1996, Salonius and Beaton 1997). Site preparation and competing vegetation control measures, that have been necessary when regenerating shade-intolerants in large canopy openings, are not required for regenerating shade-tolerants and shade-intermediates in patches and narrow strips, where competitors are much less vigorous due to modified light levels, because these species are able to grow through the early successional vegetation that develops after harvesting.

\section{Alleviation of Financial Constraints}

Altered forest harvesting behaviour that requires scattering the harvest across the landscape, longer rotations, and the maintenance of large seed trees for structural continuity, may result in some interim financial losses and decreased harvest levels for landowners in the short term. Erickson et al. (1999) stated that short-rotation management, motivated by longterm risk, short-term profits, and high discount rates may result in harvest practices that are ecologically detrimental; these authors suggested that government incentives may be necessary to influence forest landowners to alter harvest practices and rotation lengths to preserve biodiversity and forest health. Altering harvesting behaviour on Crown land, owned by the public and leased to corporations, might require decreased royalty (stumpage) rates.

\section{Summary and Conclusions}

Alternative harvesting methods that leave some mature forest structure on the landscape, and that produce regeneration microclimates that approximate those found in natural gaps, should ensure the maintenance and possibly even the restoration of Acadian forest types. Investment decisions designed to ensure supply continuity of forest products should be made in the light of future energy availability scenarios that may produce market conditions that are much different from those to which the forest industry has become accustomed during the "Petroleum Interval." 


\section{References}

Abernethy, V.D. 1997. Allowing fertility decline: 200 years after Malthus's Essay on Population. Environmental Law 27: 1097-1110. Abernethy, V.D. 2002. Fertility decline; no mystery. Ethics in Science and Environmental Politics 2002: 1-11.

Bartlett, A.A. 1978. Forgotten fundamentals of the energy crisis. American Journal of Physics 46: 876-888.

Benson, C.A. 1990. The potential for integrated resource management with extensive forest management: reconciling vision with reality-the extensive management argument. The Forestry Chronicle 66: 457-460.

Calder, K.E. 1996. Asia’s empty tank. Foreign Affairs 75: 55-69.

Campbell, C.J. 2002. Petroleum and people. Population and Environment 24: 193-207.

Campbell, C.J. and J. H. Laherrere. 1998. The end of cheap oil. Scientific American 278(3): 78-83.

Cleveland, C.J., R. Costanza, C.A.S. Hall and R. Kaufmann. 1984.

Energy and the US economy: a biophysical perspective. Science 225: 880-889.

Crow, T.R., D.S. Buckley, E.A. Nauertz and J.C. Zasada. 2002. Effects of management on the composition and structure of Northern hardwood forests in upper Michigan. Forest Science

48: 129-145.

Daly, H.E. 1991. Steady-state Economics. 2nd edition. Island Press, Washington, DC.

Deffeyes. K.S. 2001. Hubbert's Peak: the impending world oil shortage. Princeton University Press, Princeton, New Jersey.

Diamond. J.M. 1975. The island dilemma: lessons of modern biogeographic studies for the design of natural reserves. Biological Conservation 7: 129-146.

Doty, F.D. 2005. Fuels for tomorrow's vehicles. Available at http://www.dotynmr.com/PDF/Doty_FutureFuels.pdf

Duchesne, L.C. and S. Wetzel. 2003. The bioeconomy and the forestry sector: changing markets and new opportunities. The Forestry Chronicle 79: 860-864.

Dukes, J.S. 2003. Burning buried sunshine: Human consumption of ancient solar energy. Climate Change 61: 31-44.

Duncan, R.C. and W. Youngquist, 1998. The world petroleum lifecycle. Available at http://dieoff.org/page133.htm

Erickson, J.D., D. Chapman, T.J. Fahey and M.J. Christ. 1999. Nonrenewability in forest rotations: implications for economic and ecosystem sustainability. Ecological Economics 31: 91-106.

Franklin, J.F. and T.F.F. Forman.1987. Creating landscape patterns by forest cutting: Ecological consequences and principles. Landscape Ecology 1: 5-18.

Freedman, B., S. Woodley and J. Loo. 1994. Forest practices and biodiversity, with particular reference to the Maritime Provinces of eastern Canada. Environmental Reviews 2: 33-77.

Gladstone, W.T. and T.L. Ledig. 1990. Reducing pressure on natural forests through high-yield forestry. Forest Ecology and Management 35: 69-78.

Guldin, J.M. 1996. The role of uneven-aged silviculture in the context of ecosystem management. Western Journal of Applied Forestry 11: 4-12.

Hakkila, P. 2004. Developing technology for large-scale production of forest chips: Wood Energy Technology Programme 1999-2003, Technology Programme Report 6 / 2004, Final Report, TEKES, National Technology Agency, Helsinki, 2004, ISBN 952-457-151-X. Hall, C., P. Tharakan, J. Hallock, C. Cleveland and M. Jefferson. 2003. Hydrocarbons and the evolution of human culture. Nature 426: $318-322$.
Hardin, G. 1993. Living within limits: ecology, economics, and population taboos. Oxford University Press, New York.

Heinberg, R. 2005. The likely impact of global peak oil on the United States. Available at http://www.cge.uevora.pt/aspo2005/abscom/ ASPO2005_Heinberg.pdf

Ivanhoe, L.F. 1996. Updated Hubbert Curves Analyze World Oil Supply. World Oil November: 91-94.

Jaakko Pöyry Consultants. 2002. New Brunswick Forests: assessment of stewardship and management. Prepared for the New Brunswick Department of Natural Resources and the New Brunswick Forest Products Association, Fredericton, NB. 59 p.

Johnson. J.A. 1984. Small gaps created by single tree selection are not conducive to high species diversity in temperate forest types. Northern Journal of Applied Forestry 1: 69-71.

Matlack. G.R. 1994. Plant species migration in a mixed-history forest landscape in eastern North America. Ecology 75: 1491-1502.

Meadows, D.H., D.L. Meadows and J. Randers. 1992. Beyond the limits: confronting global collapse, envisioning a sustainable future. McClelland and Stewart, Toronto, Ontario.

Ohlström, M., J. Laurikko, T. Mäkinen and R. Pipatti, 2000. Greenhouse impact of biomass-based methanol use in fuel cell vehicles. Available at http://www.portalenergy.com/balpyo/ghgt5/ Papers/C5\%204.pdf

Oliver. C.D. 1999. The future of the forest management industry: highly mechanized plantations and reserves or a knowledge- intensive integrated approach. The Forestry Chronicle 75: 229-245.

Pimentel, D., R. Hartman, M. Pacenza, J. Pecarsky and M. Pimentel. 1994. Natural resources and optimum human population. Population and Environment 15: 347-367.

Pimentel, D., O. Bailey, P. Kim, E. Mullaney, J. Calabrese, L. Walman, F. Nelson and X. Yao. 1999. Will limits of the Earth's resources control human numbers? Environment, Development and Sustainability 1: 19-39.

Salonius, P. 2003. Modifying human excess with international non renewable energy taxation. ASPO Newsletter 34: Item 257. Available at http://www.peakoil.ie/newsletters/257

Salonius, P. and K. Beaton. 1997. Restoring shade tolerants in an Acadian mixed wood site of degraded species diversity, 1997. In W.H. Emmingham (compiler). Proceedings of the IUFRO Interdisciplinary Uneven-aged Management Symposium September 15-17, 1997, Corvallis, Oregon. pp. 247-258.

Smil, V. 1997. Global population and the nitrogen cycle. Scientific American 277: 76-81.

Stanton. W. 2003. The rapid growth of human populations 1750-2000: histories, consequences, issues-nation by nation. MultiScience Publishing Company Ltd.

Tainter, J. A. 1990. The collapse of complex societies. Cambridge University Press, Cambridge, U.K.

Trombulak. S.C. 1996. The restoration of old-growth: how and why. In M.B. Davis (ed.). Eastern old-growth forests: prospects for rediscovery and recovery. pp. 305-320. Island Press, Washington, DC.

Watt, K.F. 2003. What can the systems community contribute to ensure the survival of civilization. World Futures 59: 241-251.

World Commission on Economy and Environment. 1987. Our common future. Oxford University Press, Oxford, U.K.

Youngquist, W. 1997. Geodestinies: the inevitable control of Earth resources over nations and individuals. National Book Company, Portland, Oregon.

Youngquist, W. 1999. The post-petroleum paradigm-and population. Population and Environment 20: 297-315. 